\title{
MOTIVASI DALAM PEMBELAJARAN BAHASA ARAB SEBAGAI BAHASA ASING
}

\author{
Ulil Albab \\ Prodi Bahasa dan Sastra Arab UIN Raden Fatah \\ Email : ulilalbab_uin@radenfatah.ac.id
}

\begin{abstract}
Introduction. The existence of demotivating phenomena in the process of learning Arabic is very much felt by the instructor at this time, it can be seen from the low of the final result of students.

Data Collection Method. Using a study literature approach

Analysis Data. Using a descriptive analysis

Results and Discussions. There is a positive correlation to the role of motivation in language learning. This is evidenced by several studies that say that motivation can improve the results of student learning achievement. In the research conducted by Nik Mohd Rahimi Nik Yusoff, Zamri Mahamod, Kamarulzaman AB. Ghani, found that the relationship between motivation towards proficiency in hearing Arabic and achieving proficiency in hearing Arabic $(\mathrm{r}=0.613)$. This shows that the achievement of students in the ability to hear Arabic is somewhat influenced by students' motivation towards the ability to hear Arabic.
\end{abstract}

Keyword : learning motivation, arabic language, foreign language

\section{A. PENDAHULUAN}

Salah satu tantangan pengembangan pendidikan bahasa Arab di Indonesia adalah rendahnya minat dan motivasi belajar bahasa Arab, serta kecenderungan pelajar atau mahasiswa bahasa Arab untuk "mengambil jalan yang serba instan" tanpa melalui proses ketekunan dan kesungguhan. Hal ini terlihat dari karya-karya dalam bentuk makalah dan skripsi yang cenderung merosot atau kurang berbobot mutunya. Mahasiswa yang sudah berada di jurusan bahasa Arab seakan tidak betah dan ingin mencari "dunia lain". Indikatornya, tidak sedikit mahasiswa yang 
mengeluh bahwa jurusan bahasa Arab itu sebetulnya bukan "habitat" mereka yang sesungguhnya. ${ }^{1}$

Problem lemahnya motivasi belajar bahasa Arab bagi pelajar Indonesia diduga karena kurangnya perhatian guru bahasa Arab dalam meningkatkan motivasi siswanya untuk mempelajari bahasa Arab, selain karena ada stigma negatif tentang bahasa Arab yang (katanya) sulit dipelajari serta kendala lainnya. Karena itu, perlu dilakukan telaah yang mendalam tentang apa sebenarnya motivasi belajar bahasa Arab dan bagaimana strategi guru dalam memotivasi siswanya terhadap pelajaran bahasa Arab. ${ }^{2}$

Menurut Mainizar, N rendahnya kemampuan mahasiswa jurusan PBA dalam berbahasa arab adalah karena sebagian besar motivasi belajar mereka tidak ditujukan untuk menguasai bahasa yng dipelajarinya yaitu untuk dapat berintegrasi dengan pengguna bahasa yang dipelajarinya (motivasi integratif) tetapi motivasi belajar mereka ditujukan hanya untuk alasan faedah dan manfaat tertentu seperti untuk mendapatkan pekarjaan atau penghargaan sosial (motivasi instrumental), ${ }^{3}$ Seseorang yang belajar dengan motivasi integratif akan memiliki minat yang tulus dan lebih tinggi untuk menguasai bahasa yang dipelajarinya dibandingkan dengan seseorang yang belajar dengan motivasi instrumental yang

\footnotetext{
${ }^{1}$ Muhbib A. Wahab dalam "Tantangan dan Prospek Pendidikan Bahasa Arab di Indonesia", dalam Toto Edidarmo, Strategi Meningkatkan Motivasi Belajar Bahasa Arab Berdasarkan "Hierarchy Of Needs" Maslow, Affâq 'Arabiyyah | Vol. VIII, No. 1, Juni 2013 (diakses 07 Oktober 2016)

${ }^{2}$ Toto Edidarmo, Strategi Meningkatkan Motivasi Belajar Bahasa Arab Berdasarkan "Hierarchy Of Needs" Maslow, Âfâq 'Arabiyyah | Vol. VIII, No. 1, Juni 2013 (diakses 07 Oktober 2016)

${ }^{3}$ Azhar Arsyad, Bahasa Arab dan metode pengajarannya, dalam Mainizar, N, Korelasi Motivasi Belajar Bahasa Arab dengan Minat Berkomunikasi Dalam Bahasa Arab Pada Mahasiswa Jurusan Pendidikan Bahasa Arab Fakultas Tarbiyah Dan Keguruan Universitas Islam Negeri Sultan Syarif Kasim Riau, jurnal sosial budaya, vol. 8 no. 01 januari - juni 2011, (diakses 07 Oktober 2016)
} 
merasa belajar bahasa tersebut sebagai beban. Oleh karena itu motivasi belajar seseorang sangat menentukan dan besar pengaruhnya terhadap kemampuan mereka dalam berbahasa. ${ }^{4}$

Moh. Ainin menyebutkan fenomena demotivasi pembelajaran bahasa Arab di Madrasah, salah satunya merupakan dampak keberadaan Permendiknas tahun 2009, baik No. 74 maupun No. 75. Pada Permendiknas ini, mata pelajaran bahasa Arab tidak termasuk pelajaran yang di-UN-kan (diujikan secara nasional). Menurut Ainin, peraturan ini dapat diterima apabila diberlakukan untuk sekolahsekolah umum, misalnya SD, SMP, dan SMA/SMK, yang berada di bawah naungan Kementerian Pendidikan Nasional. Akan tetapi, sangat aneh jika Kementerian Agama yang mengelola madrasah, misalnya MI, MTs, MA, dan MAK, tidak menetapkan bahasa Arab sebagai matapelajaran yang di-UN-kan di lingkungannya. Apabila mata pelajaran bahasa Arab di madrasah pada berbagai jenjang ditetapkan sebagai mata pelajaran yang di-UN-kan oleh Kementerian Agama, maka fenomena demotivasi dapat diminimalkan. ${ }^{5}$

\section{B. METODE PENELITIAN}

1. Jenis Penelitian: Jenis penelitian yang digunakan dalam tulisan adalah menggunakan teknik studi literatur dengan mengumpulkan beberapa teori-

${ }^{4}$ Mainizar, N, Korelasi Motivasi Belajar Bahasa Arab dengan Minat Berkomunikasi Dalam Bahasa Arab Pada Mahasiswa Jurusan Pendidikan Bahasa Arab Fakultas Tarbiyah Dan Keguruan Universitas Islam Negeri Sultan Syarif Kasim Riau, jurnal sosial budaya, vol. 8 no. 01 januari - juni 2011, (diakses 07 Oktober 2016)

${ }^{5}$ Moh. Ainin, "Fenomena Demotivasi dalam Pembelajaran Bahasa Arab di Madrasah: Penyebab dan Alternatif Pemecahannya", dalam Mainizar, N, Korelasi Motivasi Belajar Bahasa Arab dengan Minat Berkomunikasi Dalam Bahasa Arab Pada Mahasiswa Jurusan Pendidikan Bahasa Arab Fakultas Tarbiyah Dan Keguruan Universitas Islam Negeri Sultan Syarif Kasim Riau, jurnal sosial budaya, vol. 8 no. 01 januari - juni 2011, (diakses 07 Oktober 2016) 
teori dari sejumlah buku-buku tertentu yang relevan berkaitan dengan masalah dan tujuan penelitian.

2. Teknik pengumpulan data: pengumpulan data pada penelitian ini dengan cara membaca, mencatat dan mengolah berbagai bahan penelitian dari berbagai sumber yang terkait dengan judul penelitian.

3. Teknik Analisis Data: penelitian ini menggunakan teknik analisis deskriptif yang menggambarkan dan mendeskripsikan beberapa teori-teori dan hasil penelitian tentang motivasi pembelajaran bahasa Arab.

\section{PEMBAHASAN}

1. Teori-Teori Motivasi

\section{Teori Abraham H. Maslow (Teori Kebutuhan)}

Teori motivasi yang dikembangkan oleh Abraham H. Maslow adalah Teori hierarki kebutuhan yang memandang kebutuhan manusia berjenjang dari yang paling rendah hingga paling tinggi, dimana jika suatu tingkat kebutuhan telah terpenuhi, maka kebutuhan tersebut tidak lagi berfungsi sebagai motivator. Hierarki kebutuhan Maslow adalah:

a. Kebutuhan fisik dan biologis, yaitu kebutuhan untuk menunjang kehidupan manusia seperti makanan, minuman, pakaian, dan tempat tinggal. Menurut Maslow, jika kebutuhan fisiologis belum terpenuhi, maka kebutuhan lain tidak akan memotivasi manusia;

b. Kebutuhan akan keselamatan dan keamanan, yaitu kebutuhan untuk terbebas dari bahaya fisik dan rasa takut kehilangan; 
c. Kebutuhan sosial, yaitu kebutuhan untuk bergaul dengan orang lain dan untuk diterima sebagai bagian dari yang lain;

d. Kebutuhan akan penghargaan, yaitu kebutuhan untuk dihargai oleh orang lain. Kebutuhan ini akan menghasilkan kepuasan seperti prestige, kekuasaan, status dan kebanggan atas diri sendiri;

e. Kebutuhan akan aktualisasi diri, yaitu kebutuhan untuk mengaktualisasikan semua kemampuan dan potensi yang dimiliki hingga menjadi orang seperti yang dicita-citakan. ${ }^{6}$

Kebutuhan-kebutuhan yang disebut pertama (fisiologis) dan kedua (keamanan) kadang-kadang diklasifikasikan dengan cara lain, misalnya dengan menggolongkannya sebagai kebutuhan primer, sedangkan yang lainnya dikenal pula dengan klasifikasi kebutuhan sekunder. Terlepas dari cara membuat klasifikasi kebutuhan manusia itu, yang jelas adalah bahwa sifat, jenis dan intensitas kebutuhan manusia berbeda satu orang dengan yang lainnya karena manusia merupakan individu yang unik. Juga jelas bahwa kebutuhan manusia itu tidak hanya bersifat materi, akan tetapi bersifat pskologikal, mental, intelektual dan bahkan juga spiritual. Menarik pula untuk dicatat bahwa dengan makin banyaknya organisasi yang tumbuh dan berkembang di masyarakat dan makin mendalamnya pemahaman tentang unsur manusia dalam kehidupan organisasional, teori "klasik" Maslow semakin dipergunakan, bahkan dikatakan

\footnotetext{
${ }^{6}$ Berliner, Gage, Educational Psychology, dalam Koontz, Harold. 2001. dalam Irmalia Susi Anggraini, Motivasi Belajar Dan Faktor-Faktor Yang Berpengaruh: Sebuah Kajian Pada Interaksi Pembelajaran Mahasiswa, e-journal.ikippgrimadiun.ac.id (Diakses 30 Agustus 2015)
} 
mengalami "koreksi". Penyempurnaan atau "koreksi” tersebut terutama diarahkan pada konsep "hierarki kebutuhan " yang dikemukakan oleh Maslow.

Inti teori Maslow adalah bahwa kebutuhan tersusun dalam suatu hierarki. Kebutuhan di tingkat yang paling rendah adalah kebutuhan fisiologis, dan kebutuhan di tingkat yang paling tinggi adalah kebutuhan aktualisasi diri. ${ }^{8}$

Teori McClelland (Teori Kebutuhan Berprestasi)

Dari McClelland dikenal tentang teori kebutuhan untuk mencapai prestasi atau Need for Acievement (N.Ach) yang menyatakan bahwa motivasi berbedabeda, sesuai dengan kekuatan kebutuhan seseorang akan prestasi. Murray sebagaimana dikutip oleh Winardi merumuskan kebutuhan akan prestasi tersebut sebagai keinginan :“ Melaksanakan sesuatu tugas atau pekerjaan yang sulit. Menguasai, memanipulasi, atau mengorganisasi obyek-obyek fisik, manusia, atau ide-ide melaksanakan hal-hal tersebut secepat mungkin dan seindependen mungkin, sesuai kondisi yang berlaku. Mengatasi kendala-kendala, mencapai standar tinggi. Mencapai performa puncak untuk diri sendiri. Mampu menang dalam persaingan dengan pihak lain. Meningkatkan kemampuan diri melalui penerapan bakat secara berhasil. ${ }^{9}$

Teori tiga kebutuhan berkembang diawali dengan penelitian McClelland (1961) yang mempunyai asumsi dasar bahwa kebutuhan mempunyai peran utama dalam pertumbuhan ekonomi (diasumsikan dengan prestasi suatu masyarakat). Prestasi puncak diasumsikan akan dicapai bila disertai dengan hasrat yang kuat.

\footnotetext{
${ }^{7}$ Akhmad Sudrajat, Teori-Teori Motivasi, academia.edu (Diakses 30 Agustus 2015)

${ }^{8}$ Anastasia Sri Mendari, Aplikasi Teori Hierarki Kebutuhan Maslow Dalam Meningkatkan Motivasi Belajar Mahasiswa, Widya Warta No. 01 Tahun XXXIV / Januari 2010 ISSN 0854-1981, portal.widyamandala.ac.id

${ }^{9}$ Akhmad Sudrajat, Teori-Teori Motivasi, academia.edu (Diakses 30 Agustus 2015)
} 
Penelitian yang dilakukan McClelland menggunakan teknik proyektif TAT (thematic aperseption test) dengan subjek penelitian sejumlah mahasiswa di Amerika. McClelland membandingkan jawaban-jawaban yang diberikan subjek penelitiannya, dan mengelompokkan sejumlah jawaban yang berorientasi pada beberapa gagasan yang berkaitan dengan prestasi. Kelompok jawaban itu adalah nilai untuk Achievement. ${ }^{10}$

Barelson dan Steiner dalam Koontz mendefinisikan motivasi sebagai suatu keadaan dalam diri seseorang yang mendorong, mengaktifkan atau menggerakkan, dan yang mengarahkan atau menyalurkan perilaku ke arah tujuan.

Terdapat 2 faktor yang membuat seseorang dapat termotivasi untuk belajar, yaitu: Pertama, motivasi belajar berasal dari faktor internal. Motivasi ini terbentuk karena kesadaran diri atas pemahaman betapa pentingnya belajar untuk mengembangkan dirinya dan bekal untuk menjalani kehidupan. Kedua, motivasi belajar dari faktor eksternal, yaitu dapat sekitarnya yang dapat memengaruhi psikologis orang yang bersangkutan. ${ }^{11}$

Berdasarkan berbagai definisi tentang motivasi, disimpulkan motivasi belajar mahasiswa adalah sebagai suatu keadaan dalam diri mahasiswa yang mendorong dan mengarahkan perilakunya pada tujuan yang ingin dicapainya dalam mengikuti pendidikan tinggi. Idealnya, tujuan mahasiswa dalam mengikuti pendidikan tinggi adalah untuk menguasai bidang ilmu yang dipelajarinya.

\footnotetext{
${ }^{10}$ McClelland, D. C., Atkinson, J. W., Clark, R. A., \& Lowell, E. L., 1953, The Achievement Motive,dalam Ayu Dwi Nindyati, Kepribadian Dan Motivasi Berprestasi (Kajian Big Five Personality), Jurnal psikodinamik, 2006 - researchgate.net (Diakses 30 Agustus 2015)

${ }^{11}$ Berliner, Gage, 1993, Educational Psychology, dalam Koontz, Harold. 2001. Manajemen dalam Irmalia Susi Anggraini, Motivasi Belajar Dan Faktor-Faktor Yang Berpengaruh: Sebuah Kajian Pada Interaksi Pembelajaran Mahasiswa, $e$ journal.ikippgrimadiun.ac.id (Diakses 30 Agustus 2015)
} 
Sehingga dalam mempelajari setiap bahan pembelajaran, mahasiswa terdorong untuk menguasai bahan pembelajaran tersebut dengan baik, dan bukan hanya untuk sekedar lulus meski dengan nilai yang sangat baik sekalipun. Meski secara konseptual tidak ada perbedaan antara menguasai bahan pembelajaran dengan baik dan mendapat nilai baik untuk bahan pembelajaran tersebut, namun dalam dunia pendidikan tinggi swasta di Indonesia dewasa ini, seorang mahasiswa yang lulus dalam suatu bahan pembelajaran dengan nilai baik, belum tentu menguasai bahan pembelajaran tersebut dengan baik. Sebaliknya, jika seorang mahasiswa mampu menguasai suatu bahan pembelajaran dengan baik, maka hampir dapat dipastikan bahwa dia akan lulus dalam bahan pembelajaran tersebut dengan nilai baik pula. $^{12}$

\section{Teori Clyton Alderfer (Teori "ERG)}

Clayton Alderfer mengembangkan teori yang disebut Existence, Relatedness, and Growth (ERG) theory (eksistensi, hubungan dan pertumbuhan), yang dapat dikatakan sebagai rangkuman dari teori kebutuhan hierarkis dari Maslow, hanya saja menurut Alderfer masing-masing kebutuhan tersebut dapat dipenuhi kapan saja tanpa harus ada yang dipenuhi terlebih dahulu, atau ada kebutuhan yang lebih rendah dibandingkan dengan kebutuhan lainnya. ${ }^{13}$

Berbeda dengan teori hierarki kebutuhan, teori ERG memperlihatkan bahwa dapat beroperasi sekaligus lebih dari satu kebutuhan, dan jika kepuasan dari suatu kebutuhan tingkat-lebih-tinggi tertahan, hasrat untuk memenuhi

\footnotetext{
${ }^{12}$ Irmalia Susi Anggraini, Motivasi Belajar Dan Faktor-Faktor Yang Berpengaruh: Sebuah Kajian Pada Interaksi Pembelajaran Mahasiswa, e-journal.ikippgrimadiun.ac.id (Diakses 30 Agustus 2015)

${ }^{13}$ Anies S. Basalamah, Mengenali Motivasi Untuk Meningkatkan Kinerja, www.kemenkeu.go.id. 2011, (diakses 05-Oktober 2016)
} 
kebutuhan tingkat-lebih-rendah meningkat. Hierarki kebutuhan Maslow mengikuti kemajuan yang bertingkat-tingkat dan kaku. Teori ERG tidak mengandaikan suatu hierarki yang kaku di mana kebutuhan yang lebih rendah harus lebih dahulu cukup banyak dipuaskan sebelum orang dapat maju terus. Misalnya, seseorang dapat mengusahakan pertumbuhan meskipun kebutuhan eksistensi dan hubungan belum dipuaskan; atau ketiga kategori kebutuhan dapat beroperasi sekaligus. ${ }^{14}$

Teori ERG juga mengandung suatu dimensi frustrasi-regresi. Maslow berargumen bahwa seorang individu akan tetap pada suatu tingkat kebutuhan tertentu sampai kebutuhan tersebut dipenuhi. Teori ERG menyangkalnya dengan mengatakan bahwa bila suatu tingkat kebutuhan dari urutan-lebih-tinggi terhalang, akan terjadi hasrat individu itu untuk meningkatkan kebutuhan tingkat lebih-rendah

Ketidak-mampuan memuaskan suatu kebutuhan akan interaksi sosial, misalnya, mungkin meningkatkan hasrat memiliki lebih banyak uang atau kondisi kerja yang lebih baik. Jadi frustrasi (halangan) dapat mendorong pada suatu kemunduran ke kebutuhan yang lebih rendah. ${ }^{15}$

Ringkasnya, teori ERG berargumen, seperti Maslow, bahwa kebutuhan tingkat lebih-rendah yang terpuaskan menghantar ke hasrat untuk memenuhi kebutuhan tingkat lebih-tinggi; tetapi kebutuhan ganda dapat beroperasi sebagai motivator sekaligus, dan halangan dalam mencoba memuaskan kebutuhan tingkat

\footnotetext{
${ }^{14}$ Yulianto Kadji, Tentang Teori Motivasi, Jurnal INOVASI Volume 9, No.1, Maret 2012 ISSN 1693-9034 (diakses 05 Oktober 2016)

${ }^{15}$ Yulianto Kadji, Tentang Teori Motivasi, Jurnal INOVASI Volume 9, No.1, Maret 2012 ISSN 1693-9034 (diakses 05 Oktober 2016)
} 
lebihtinggi dapat menghasilkan regresi ke suatu kebutuhan tingkat lebih-rendah. Teori ERG lebih konsisten dengan pengetahuan kita mengenai perbedaan individual di antara orang-orang. Variabel seperti pendidikan, latar belakang keluarga, dan lingkungan budaya dapat mengubah pentingnya atau kekuatan dorong yang dipegang sekelompok kebutuhan untuk seorang individu tertentu. ${ }^{16}$

\section{Pembelajaran Bahasa}

\section{Pengertian Belajar}

Belajar adalah suatu proses usaha yang dilakukan seseorang untuk memperoleh suatu perubahan tingkah laku yang baru secara keseluruhan sebagai hasil pengalamannya sendiri dalam interaksi dengan lingkungannya. Dalam buku yang lain Oemar Hamalik menyatakan bahwa "belajar adalah suatu proses, suatu usaha, kegiatan dan bukan suatu hasil atau tujuan yang bukan hanya mengingat, akan tetapi lebih luas dari itu, yaitu mengalami dan hasilnya bukan suatu penguasaaan hasil latihan melainkan perubahan kelakuan”. Lebih lanjut Sardiman mengatakan bahwa belajar itu senantiasa merupakan perubahan tingkah laku atau penampilan dengan serangkaian kegiatan misalnya dengan membaca, mengamati, mendengarkan, meniru dan lain sebagainya. ${ }^{17}$

Slameto mengemukakan bahwa belajar adalah serangkaian kegiatan jiwa raga untuk memperoleh suatu perubahan tingkah laku sebagai hasil dari pengalaman individu dalam interaksi dengan lingkungannya menyangkut kognitif, afektif, dan psikomotorik. Dalam belajar, siswa mengalami sendiri proses dari

\footnotetext{
${ }^{16}$ Yulianto Kadji, Tentang Teori Motivasi, Jurnal INOVASI Volume 9, No.1, Maret 2012 ISSN 1693-9034 (diakses 05 Oktober 2016)

${ }^{17}$ Nandang Sarip Hidayat, Problematika Pembelajaran Bahasa Arab, Jurnal Pemikiran Islam; Vol. 37, No. 1 Januari-Juni 2012, (diakses 30 Agustus 2016)
} 
tidak tahu menjadi tahu. ${ }^{18}$ Tingkat partisipasi aktif peserta didik dalam proses belajar merupakan salah satu indikator proses belajar yang berkualitas. Rasa keterlibatan yang dilandasi oleh motivasi dan minat yang tinggi dari pihak peserta didik dalam mengikuti proses belajar di kelas merupakan indikator dari proses yang berkualitas. ${ }^{19}$

Pengertian Mengajar

Menurut pandangan William H.Burton, dkk: "mengajar adalah upaya dalam memberikan perangsang, bimbingan, pengarahan, dan dorongan kepada siswa agar terjadi proses belajar". Terkait dengan mengajar Sardiman juga mengemukakan dalam bukunya "mengajar adalah suatu usaha untuk menciptakan kondisi atau sistem lingkungan yang mendukung dan memungkinkan untuk berlangsungnya proses belajar". Sama halnya dengan belajar, mengajarpun menurut Nana Sudjana pada hakikatnya "mengajar adalah suatu proses, yakni proses mengatur, mengorganisasi lingkungan yang ada di sekitar siswa sehingga dapat menumbuhkan dan mendorong siswa melakukan proses belajar". ${ }^{20}$

\section{Motivasi Dalam Pembelajaran Bahasa}

Motivasi dalam pembelajaran bahasa mempunyai berbagai macam upaya diantaranya adalah pemakaian strategi pembelajaran bahasa seperti dalam penelitian "korelasi strategi dengan motivasi dalam pembelajaran bahasa arab".

\footnotetext{
${ }^{18}$ Slameto, Belajar dan Faktor-faktor yang Mempengaruhinya dalam Ghullam Hamdu, Lisa Agustina, Pengaruh Motivasi Belajar Siswa Terhadap Pestasi Belajar IPA di Sekolah Dasar (Studi Kasus terhadap Siswa Kelas IV SDN Tarumanagara Kecamatan Tawang Kota Tasikmalaya), Jurnal Penelitian Pendidikan 81 Vol. 12 No. 1, April 2011, (diakses 31 Agustus 2016)

${ }^{19}$ A. Hasan Saragih, Kompetensi Minimal Seorang Guru Dalam Mengajar, Jurnal Tabularasa PPS UNIMED, Vol.5 No.1, Juni 2008 (diakses 31 Agustus 2016)

${ }^{20}$ Nandang Sarip Hidayat, Problematika Pembelajaran Bahasa Arab, Jurnal Pemikiran Islam; Vol. 37, No. 1 Januari-Juni 2012, (diakses 30 Agustus 2016)
} 
Penelitian ini menunjukkan bahwa adanya Korelasi positif dan hubungan linear yang terdapat antara motivasi pembelajaran bahasa dengan penggunaan SPB (Strategi Pembelajaran Bahasa) telah menguatkan keterangan mengenai peranan teori kognitif sosial sebagai salah satu teori SPB.

Penelitian ini juga telah mengukuhkan teori psikologi sosial MacIntyre dan teori sosio pembelajaran Gardner yang melihat motivasi sebagai salah satu faktor utama dalam pembelajaran bahasa dan penggunaan SPB. Teori-teori tersebut berkeyakinan bahwa motivasi merupakan elemen asas dan penting bagi menggalakkan penggunaan pelbagai SPB secara kontinyu. Dengan kata lain, pelajar yang bermotivasi tinggi akan kerap menggunakan SPB berbanding pelajar bermotivasi rendah. Bertolak daripada itu, hasil kajian ini membawa kepada beberapa implikasi pedagogi. Antaranya, pelajar bahasa perlu dibimbing supaya menyadari tentang proses pembelajaran dan strategi-strategi pembelajaran yang digunakan oleh mereka. Guru tidak harus berperanan sebagai penyampai informasi semata, mereka perlu bertindak sebagai pembimbing dan supervisor pelajar. Mereka juga perlu membina dan meningkatkan motivasi pembelajaran bahasa pelajar agar minat mereka untuk mempelajari dan menggunakan bahasa Arab meningkat. Pihak sekolah juga hendaklah menyediakan suasana pembelajaran bahasa yang diperkaya dengan lebih banyak sumber dan peluang bagi pelajar untuk belajar, berlatih dan menggunakan bahasa Arab. Suasana 
pembelajaran dapat memupuk dan meningkatkan tahap motivasi serta penggunaan strategi pembelajaran bahasa pelajar..$^{21}$

Dalam penelitian kedua yang berjudul "Motivasi Pembelajaran Kemahiran Mendengar Bahasa Arab dan Hubungannya dengan Pencapaian Pelajar", Berdasarkan hasil penelitian dapat dibuat suatu rumusan bahwa motivasi yang tinggi dalam pembelajaran kemahiran mendengar bahasa Arab sebagai bahasa kedua mempunyai hubungan yang signifikan dengan pencapaian pelajar. Kajiankajian yang berkaitan menunjukkan bahawa motivasi pelajar merupakan salah satu faktor yang dapat mempengaruhi tahap pencapaian pelajar, karena motivasi dapat mempengaruhi apa, mana dan bagaimana kita belajar. Motivasi bukan saja mempengaruhi hasil tetapi apa yang dilakukan dan dipelajari juga mempengaruhi motivasi selanjutnya. Penelitian ini juga menemukan bahwa hubungan antara motivasi terhadap kemahiran mendengar bahasa Arab dengan pencapaian kemahiran mendengar bahasa Arab $(r=0.613)$.

Ini menunjukkan pencapaian pelajar-pelajar dalam kemahiran mendengar bahasa Arab sedikit sebanyak dipengaruhi oleh motivasi pelajar-pelajar terhadap kemahiran mendengar bahasa Arab. Sekaligus ini menunjukkan pelajar-pelajar yang mempunyai motivasi yang tinggi terhadap kemahiran mendengar bahasa Arab juga mendapat hasil yang tinggi dalam kemahiran mendengar bahasa Arab. Uji korelasi ini diperkukuhkan lagi oleh dalam uji anova yang menunjukkan perbedaan antara tiga kumpulan motivasi tinggi, sederhana dan rendah. Mengikut

${ }^{21}$ Kamarul Shukri Mat Teh, Mohamed Amin Embi, Korelasi Strategi Dengan Motivasi Dalam Pembelajaran Bahasa Arab (The Correlation Between Language Learning Strategies And Motivation In Arabic Language Learning), Jurnal Pendidik dan Pendidikan, Jil. 24, 109-123, 2009, (diakses 30 Agustus 2016) 
Lightbown dan Spada (1999) motivasi yang tinggi biasanya lahir dari dalam diri pelajar bahasa kedua yang dipelajari, iaitu mereka belajar bahasa Arab atas kemahuannya sendiri. Justeru secara tidak langsung, ini menunjukkan pelajarpelajar mempelajari bahasa Arab bukan kerana tekanan luar. Adapun pelajar yang mempelajari bahasa kedua atas kemauan ibu bapaknya, bukannya atas kemauannya sendiri maka motivasi menjadi rendah. Seperti teori Gadner dan Lambert jika seseorang pelajar itu mempelajari bahasa kedua dengan tekanan luar, maka motivasi pelajar itu akan menjadi rendah. ${ }^{22}$

Sikap terhadap pembelajaran bahasa juga mempengaruhi proses pembelajaran. Keadaan ini disebut dengan motivasi intristik, motivasi ini mempunyai dampak kepada pelajar untuk menekuni bahasa Arab. Penelitian ini juga membuktikan bahwa faktor ini sangat penting karena memberikan kesan positif terhadap proses pembelajaran, ini juga dapat dilihat dari segi ketekunan mereka serta mengetahui lebih lanjut tentang kemahiran bahasa Arab. Terdapat pula pelajar yang menyatakan keinginan untuk meneruskan pembelajaran bahasa Arab setelah selesai belajar di universitas dimasa mendatang. ${ }^{23}$

Penelitian Mainizar, $\mathrm{N}$ menyimpulkan bahwa, bila dilihat rata-rata persentase motivasi belajar bahasa arab $(84,40 \%)$ dan minat berkomunikasi dalam bahasa Arab (78,80). Maka persentase motivasi belajar jauh lebih tinggi dari minat berkomunikasi yaitu sebesar $6,40 \%$, walaupun masih sama-sama dalam

\footnotetext{
${ }^{22}$ Nik Mohd Rahimi Nik Yusoff, Zamri Mahamod, Kamarulzaman AB. Ghani, Motivasi Pembelajaran Kemahiran Mendengar Bahasa Arab dan Hubungannya dengan Pencapaian Pelajar, Jurnal Pendidikan 33 (2008) 3-18 http://www.ukm.my/

${ }^{23}$ Ghazali Yusri, Nik Mohd Rahimi, Parilah M. Shah, Sikap Pelajar Terhadap Pembelajaran Kemahiran Lisan Bahasa Arab Di Universiti Teknologi MARA (UiTM), GEMA Online $^{\mathrm{TM}}$ Journal of Language Studies, Volume 10(3) 2010 (diakses 05 Oktober 2016)
} 
kategori tinggi. Jadi dapat disimpulkan bahwa kurang mampunya mahasiswa berkomunikasi dengan bahasa arab disebabkan kurangnya minat berkomunikasi dengan bahasa arab. Hal ini juga menunjukkan bahwa minat berkomunikasi tidak seimbang dengan motivasi belajar. Apabila motivasi belajar yang tinggi diiringi atau sejajar dengan minat berkomunikasi bahasa arab, maka kemampuan berkomunikasi bahasa arab mahasiswa akan meningkat. ${ }^{24}$

\section{HASIL DAN KESIMPULAN}

Dari beberapa penelitian diatas dapat disimpulkan bahwa motivasi mempunyai hubungan yang signifikan dengan hasil belajar siswa. Strategi belajar bahasa Arab seperti buku yang memadai, lingkungan sekolah yang mendukung terhadap suasana pembelajaran, serta guru yang bertindak sebagai penyedia dan fasilitator serta motivator informasi peluang belajar bahasa menjadikan pelajar termotivasi dalam pembelajaran bahasa.

Motivasi dalam proses belajar mengajar terkhusus pada pembelajaran bahasa sangat diperlukan, mengingat perbedaan antara bahasa ibu dan bahasa kedua sangatlah berbeda. Dengan diberikannya motivasi oleh guru sebagai pembimbing dan sekolah sebagai penyedia fasilitas maka minat belajar pelajar siswa dan hasil capaian pembelajaran bahasa akan meningkat.

\footnotetext{
${ }^{24}$ Mainizar, N, Korelasi Motivasi Belajar Bahasa Arab dengan Minat Berkomunikasi Dalam Bahasa Arab Pada Mahasiswa Jurusan Pendidikan Bahasa Arab Fakultas Tarbiyah Dan Keguruan Universitas Islam Negeri Sultan Syarif Kasim Riau, jurnal sosial budaya, vol. 8 no. 01 januari - juni 2011, (diakses 07 Oktober 2016)
} 


\section{DAFTAR PUSTAKA}

Anggraini, Irmalia Susi., Motivasi Belajar Dan Faktor-Faktor Yang Berpengaruh: Sebuah Kajian Pada Interaksi Pembelajaran Mahasiswa, ejournal.ikippgrimadiun.ac.id (Diakses 30 Agustus 2015)

Basalamah, Anies S., Mengenali Motivasi Untuk Meningkatkan Kinerja, www.kemenkeu.go.id. 2011, (diakses 05-Oktober 2016)

Berliner, Gage, Educational Psychology, dalam Koontz, Harold. 2001. dalam Irmalia Susi Anggraini, Motivasi Belajar Dan Faktor-Faktor Yang Berpengaruh: Sebuah Kajian Pada Interaksi Pembelajaran Mahasiswa, $e$ journal.ikippgrimadiun.ac.id (Diakses 30 Agustus 2015)

D. C, McClelland., Atkinson, J. W., Clark, R. A., \& Lowell, E. L., 1953, The Achievement Motive,dalam Ayu Dwi Nindyati, Kepribadian Dan Motivasi Berprestasi (Kajian Big Five Personality), Jurnal psikodinamik, 2006 researchgate.net (Diakses 30 Agustus 2015)

Edidarmo, Toto., Strategi Meningkatkan Motivasi Belajar Bahasa Arab Berdasarkan "Hierarchy Of Needs" Maslow, Âfâq 'Arabiyyah | Vol. VIII, No. 1, Juni 2013 (diakses 07 Oktober 2016)

Hidayat, Nandang Sarip., Problematika Pembelajaran Bahasa Arab, Jurnal Pemikiran Islam; Vol. 37, No. 1 Januari-Juni 2012, (diakses 30 Agustus 2016)

Kadji, Yulianto., Tentang Teori Motivasi, Jurnal INOVASI Volume 9, No.1, Maret 2012 ISSN 1693-9034 (diakses 05 Oktober 2016)

Mat Teh, Kamarul Shukri., Mohamed Amin Embi, Korelasi Strategi Dengan Motivasi Dalam Pembelajaran Bahasa Arab (The Correlation Between Language Learning Strategies And Motivation In Arabic Language Learning), Jurnal Pendidik dan Pendidikan, Jil. 24, 109-123, 2009, (diakses 30 Agustus 2016)

Mendari, Anastasia Sri., Aplikasi Teori Hierarki Kebutuhan Maslow Dalam Meningkatkan Motivasi Belajar Mahasiswa, Widya Warta No. 01 Tahun XXXIV / Januari 2010 ISSN 0854-1981, portal.widyamandala.ac.id

Nik Yusoff, Nik Mohd Rahimi., Zamri Mahamod, Kamarulzaman AB. Ghani, Motivasi Pembelajaran Kemahiran Mendengar Bahasa Arab dan Hubungannya dengan Pencapaian Pelajar, Jurnal Pendidikan 33 (2008) 318 http://www.ukm.my/

N, Mainizar., Korelasi Motivasi Belajar Bahasa Arab dengan Minat Berkomunikasi Dalam Bahasa Arab Pada Mahasiswa Jurusan Pendidikan Bahasa Arab Fakultas Tarbiyah Dan Keguruan Universitas Islam Negeri 
Sultan Syarif Kasim Riau, jurnal sosial budaya, vol. 8 no. 01 januari juni 2011, (diakses 07 Oktober 2016)

Saragih, A. Hasan., Kompetensi Minimal Seorang Guru Dalam Mengajar, Jurnal Tabularasa PPS UNIMED, Vol.5 No.1, Juni 2008 (diakses 31 Agustus 2016)

Sudrajat, Akhmad., Teori-Teori Motivasi, academia.edu (Diakses 30 Agustus 2015)

Slameto, Belajar dan Faktor-faktor yang Mempengaruhinya dalam Ghullam Hamdu, Lisa Agustina, Pengaruh Motivasi Belajar Siswa Terhadap Pestasi Belajar IPA di Sekolah Dasar (Studi Kasus terhadap Siswa Kelas IV SDN Tarumanagara Kecamatan Tawang Kota Tasikmalaya), Jurnal Penelitian Pendidikan 81 Vol. 12 No. 1, April 2011, (diakses 31 Agustus 2016)

Yusri, Ghazali., Nik Mohd Rahimi, Parilah M. Shah, Sikap Pelajar Terhadap Pembelajaran Kemahiran Lisan Bahasa Arab Di Universiti Teknologi MARA (UiTM), GEMA Online ${ }^{\mathrm{TM}}$ Journal of Language Studies, Volume 10(3) 2010 (diakses 05 Oktober 2016) 